The Brock Review Volume 10 (2008)

(C) Brock University

\title{
Earthways: Opportunity, Community and Meaning in the Personal Garden
}

\author{
Renate Sander-Regier \\ Department of Geography \\ University of Ottawa
}

\begin{abstract}
The hybrid space of the personal garden offers valuable opportunities for individuals to express themselves personally in an outdoor setting, to develop meaningful relationships with green spaces, and to connect with the greater natural environment and urban community, as demonstrated in the works of contemporary gardener-authors Marjorie Harris, Sara Stein, and Leon Whiteson. These opportunities are particularly significant in urban environments where access to nature and green space is limited, and where gardening activities can contribute to the health of the natural environment, the wellbeing of people involved in the space, and the vitality of the community at large.
\end{abstract}

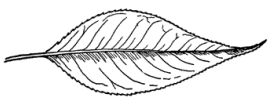

I believe that we garden, essentially, to participate in the planet and, through this, change the world and be changed by it'.

"A garden is a place where someone spends a few hours each day in a wild place he tries to shape to his desire. It's a place of harmony, of balance, and it is made from living things". 2 In this deceptively straightforward definition of the personal garden — also called "home" garden", "private" garden", "domestic" garden", "backyard" garden", or "house lot" garden", depending on the context - Canadian poet and gardener Patrick Lane captures the human-"natural" complexity at the core of this intriguing and multifaceted space. Entwined and interconnected, the personal garden's human and "natural" qualities open up space and opportunity for significant and unpredictable things to happen. In urban settings in particular, garden spaces offer valuable opportunities for individuals to express themselves personally in an outdoor setting, to develop meaningful relationships with a green space, and to reach beyond the immediate garden boundaries to connect with the greater environment.

Not all urban gardeners take full advantage of these opportunities, but as contemporary personal gardening authors Marjorie Harris, Sara Stein, and Leon Whiteson illustrate, the potential definitely exists for those willing to open themselves to the garden's dynamics. Gardening writer Marjorie Harris - author of Seasons of my Garden (1999) and In the Garden: thoughts on changing seasons (1996) ${ }^{10}$ among other titles - lives and gardens in Toronto, Ontario. Sara Stein, author of Noab's Garden: restoring the ecology of our own backyards (1993) and other garden-related books, was a prolific science writer who cultivated a large suburban acreage in Pound Ridge, New York. ${ }^{11}$ Architect, novelist and 
non-fiction writer Leon Whiteson wrote A Garden Story (1999) about the garden he tends in downtown Hollywood, California.

Although they garden in varied urban settings, and in different social, cultural and environmental contexts - which they variously discuss - all three authors make the most of the chance to express themselves in their outdoor urban garden spaces, and to connect to a greater whole. Their books are highly personal, creative non-fiction accounts of how their gardens originated, how the spaces evolved, and how unique relationships developed between themselves, the mini-landscapes they cultivate, and beyond. Each of these gardener-authors - as they imagine, shape, and maintain the garden over time, as they ponder the evolution and meaning of the space, as they tell their personal gardening stories - provides a unique and rich perspective on the significance of the personal garden to city residents and to the urban and suburban environment and community.

\section{Garden complexity, garden hybridity}

Hybridity is described as a process or thing which crosses and displaces binary boundaries, and in so doing produces something "ontologically new". ${ }^{2}$ A hybrid is something which carries physical traces of the originating elements, yet emerges as a "distinct entity", a "thing in its own right". ${ }^{13}$ If we consider the personal garden in this light, its human-natural complexity takes on decidedly hybrid tones. Neither totally natural, nor totally human, gardens are characterized by strong social, cultural and personal elements, and by complex webs of biological, ecological and environmental relations, with each garden emerging as a unique entity according to its human design and physical setting.

As spaces shared variously with family, friends and the greater community, essentially settings for contact and interaction, gardens have strong social elements. They are also undeniably cultural, in terms of the human vision and imagination involved in designing the structure of the space, and the varied physical work of digging and planting to shape the space, plus the weeding, pruning, mulching, fertilising, raking, watering, and more to maintain the garden's desired characteristics. Gardens are also intensely personal and intimate, with each individual gardener developing a unique attachment to the space, and each space carrying particular meaning for the gardener. ${ }^{14}$

Yet gardens are also typically populated and visited by biological entities such as plants, soil organisms, and insects, as well as species of birds, reptiles, amphibians and mammals. These biological entities engage in a wide variety of complex and necessary relationships with each other and with the garden environment. And the garden environment is dependent on and subject to greater ecological and environmental processes and systems involved in producing nutrients in the soil, bringing sunlight and water to the space, and producing changes in seasons and climate. ${ }^{15}$ It is important to note that the gardener is among the biological organisms active in the garden space, where she or he participates as an element of both the ecological community within the garden and the greater natural system beyond the garden's boundaries.

The result of this human-natural hybridity is a space that is complex, distinct and unique, reflecting not only the fancies, intentions and activities of the individual gardener, but also the specific environmental conditions of the garden site. Geographer Gillian Rose adds that hybridity implies the need to think of space differently and to recognise new spaces, such as those of flows and connections rather than territories. ${ }^{16}$ Flows and connections - between the garden's human and natural elements, between the gardener's vision and nature's systems, between maintenance tasks and ecological activity - characterize the gardens of Marjorie Harris, Sara Stein and Leon Whiteson, as they evolve through time and through emerging relationships.

\section{Personal Expression}


Our human landscape is our unwitting autobiography, reflecting our tastes, our values, our aspirations, and even our fears, in tangible, visible form. ${ }^{17}$

Marjorie Harris, Leon Whiteson, and Sara Stein all take advantage of opportunities offered by the hybrid spaces of their personal gardens to express themselves personally — each individual working within the particularities of the space and the peculiarities of his or her own values and motivations.

\section{Creative expression - artistry}

In her downtown Toronto garden, Marjorie Harris seeks undulations of colour and an overall "vibrant and sensual picture" — an unmistakably visual and aesthetic approach, one that likely reflects the many years she worked in an art gallery, ${ }^{18}$ combined with her own desire for creative expression. "I remember looking at a garden book many years ago", she writes, "and thinking, I can do that, when I saw two plants that looked so perfect together they almost seemed like a painting". 19 She asserts, in fact, that a good garden is like a great painting in that it unfolds itself "with infinite subtlety, never revealing its secrets all at once", particularly in terms of colour.

Those realizations, however, come long after she has her initial creative garden epiphany one winter morning while drinking coffee and practising what she calls "creative staring" 21 at the snow on the garden. All of a sudden, she states, "I found that it was the spaces I was looking into. My mind wasn't cluttered with the fact of plants, or plant color, or plant volume. There was just space in front of me", 22 space that held out opportunity for expression. This realization was followed by a vision of what the garden should look like: "divided into rooms, a checkerboard pattern in place, an intense planting of trees, shrubs and perennials making a living picture - in vivid color". ${ }^{23}$ This checkerboard pattern eventually takes shape and grows into a tapestry, with a wide variety of elements "artfully interwoven" ${ }^{24}$ for visual effect.

Form is important to Harris' personal expression as well, a fact she appreciates in the winter when she spends less time working in the garden, and more time looking at it. ${ }^{25}$ She has particular admiration for the way evergreen trees hold the snow, for their shapes under the snow, for their contributions to "the choreography of the winter garden." ${ }^{26}$ Harris obtains additional form and colour aesthetics by adding a wide variety of plant containers, "the backbone of the summer garden", ${ }^{27}$ to her garden space. Harris' garden is a continual process of creative staring, imagining, designing, rearranging and filling, in a constant effort to achieve what she calls pleasing the eye. ${ }^{28}$

\section{Creative expression - fusion}

Leon Whiteson is another gardener-author who seeks to please the eye, although his approach is more structural. He describes, for example, the first critical architectural gaze he casts on the neglected garden space in what appears to be an almost subconscious evaluation of its aesthetic potential. "My trained architect's eye," he writes, "registered that there was no intermediate scale of plants to mediate between them [the trees] and the plane of bare earth. The old avocado tree was dropping its inedible fruit on the dry grass.... The birds and squirrels were ... nibbling the rangy orange tree, dropping fruit onto the deck, splattering juice and pulp over the redwood planks" 29 not a positive impression.

But later, after deciding to design a garden that would improve the derelict space, he recognizes that it holds more structural potential than he first realised. "The linked branches of a stunted orange tree and the lower limbs of the tall avocado formed a natural arch dividing the back area of the yard from the middle," he writes. "The deck steps made an easy transition down to the ground, acting as a curtain raiser opening the inside to the outside. Other sequences became obvious" 30 . This realization leads Whiteson to a creative garden epiphany not unlike Harris' when, early one morning, 
he sits down to draw a plan of the garden. At that point, he appears to exchange his trained architect's eye for his novelist's imagination - a flight of fancy that conceptualizes the garden as a sort of "green novel":

The various zones suggested by the shape of the yard and the placement of the existing trees could be chapters organizing a green plot.... I saw that my yard easily fell into visual chapters. One chapter opened directly off the main deck. Beyond it, at the back of the yard, separated by the avocado and an orange tree, was another smaller chapter in this potential verdant tale.... The two decks, back and side, offered further narrative sequences.

The plants, shrubs and trees, he adds, could be placed to weave a host of themes into "a vivid horticultural narrative" 31 ; they could be clustered as paragraphs, with single plants acting as sentences or phrases to keep the garden story moving ${ }^{32}$. Whiteson weaves the green novel theme throughout the book with reference to "narrative character" 33 and "narrative detail" 34 contributed by various artefacts he adds to the garden landscape.

These artefacts are colourful, diverse, eccentric, and often scavenged. Whiteson gathers seed pods and fallen branches from the streets, steals stop signs and municipal parking notices that have been knocked down. He salvages a white pedestal wash-basin from the garbage, and buys a dressmaker's cane dummy and cement gargoyle at local yard sales. All these objects, he reports, find places among the plants without cluttering the space ${ }^{35}$. Some find their way into garden totem poles, while others - a green-painted wooden frog tapping a red drum, a small wooden train engine and carriages - become quirky garden containers filled with flowers and nailed to the wooden deck, ${ }^{36}$ adding a touch of comedy and eccentricity to a space heavy with meaning, as will be illustrated in the next section.

\section{Ecological expression - responsibility}

Sara Stein's garden, in contrast, appears to have nothing particularly comical or quirky about it. Stein does not manifest a need to express herself creatively in the garden. She has a clear, practical purpose for the space from the outset: to provide a variety of habitats to as wide a spectrum of wildlife as possible. What makes this goal a personal expression is its origins in feelings of intense responsibility for the land, and unwavering stewardship of the space following the damage she initially inflicted upon it. As she explains in the first chapter of Noah's Garden:

When Marty and I bought our land, it was in just that stage of regrowth from pasture to forest that is among the most productive ecosystems on earth. It was covered with brambles, bushes, vines, and grasses that supported a large and varied animal population. Our footsteps stirred up flights of grouse, grasshoppers that rose on rattling wings, and panicky rabbits. Frogs of assorted size and voice croaked loudly by the pond. A woodchuck family lived below a large boulder; a fox had its den nearby.

This was the sort of land that real estate agents, embarrassed by its unkempt appearance, describe as "having potential." Here, where the goldenrod smelled rank in late summer, could be a lawn; there, beneath tangled vines, a rockery; the young and gawky woodland verge would be much improved by removing the undergrowth.

We did all this and more. We cleared brush and pulled vines and hauled rocks and broke ground and dug beds until, after years of high hopes and hard work, we had an expanse of landscaped grounds and gardens that seemed to us like Eden.

Then it hit. I realized in an instant the full extent of what we had done: we had banished the 
animals from this paradise of ours. ${ }^{37}$

Stein and her husband had subscribed to the dominant North American landscaping tradition, which the author later describes as "Yards and gardens patched with grass and stitched with hedges all across America ... a vast, nearly continuous, and terribly impoverished ecosystem". ${ }^{38}$ The rest of the book is about their efforts to undo the ecological devastation they wrought upon their land.

Stein's inspiration for this endeavour comes not from her creative self, but from the natural environment and ecological relationships she spends months both observing in the landscape around her, and studying in books in an attempt to understand the "awesomely complicated and almost incredible tales" in operation "out there", ${ }^{40}$ a system too complicated to comprehend fully, but not terribly difficult to follow. The basic outlines of the plan, she points out, are visible in the fields, forests and wetlands still existing in the surrounding landscape, or in protected natural areas. She adds that we needn't worry about the fine details — that the picture will fill itself in if it gets off to a good start. ${ }^{41}$

Stein and her husband start by planting fruiting shrubs in garden islands, then joining isolated garden patches, and adding hedgerows and thickets to link the various patches to the woodlands. ${ }^{42}$ They also replant the pond with native species, ${ }^{43}$ establish a prairie patch which they burn periodically, ${ }^{44}$ and weave the pieces together with native grasses and wildflowers. ${ }^{45}$ And their efforts yield results, as the following view from her attic office window reveals:

... splashed with fruit: crowds of orange crabapples, tiers of crimson dogwood berries, drapes of Virginia creeper hung with sprays of blue. Opening the window, I hear the patter of falling acorns

and thunks of hickory nuts.... Every longing glance outdoors — every pause to grope for the next word — finds a chipmunk hurrying along the garden wall and squirrels furiously digging in garden

beds. Any day now, a flock of cedar waxwings will descend to strip the berries from the crabapples just below me. ${ }^{46}$

Elsewhere she reports the return of meadowlarks, bluebirds and butterflies, and the increase of tadpoles and fish fry in the pond. ${ }^{47}$ More subtly, a screen of white pines planted for privacy ends up offering a refuge for over-wintering cardinals, while brick paving laid in sand instead of concrete provides space for ants to make their constructions, as well as food for flickers who feed on the ants. $^{48}$ All these results have significant personal reward and meaning for Stein. When a garden comes alive ecologically, she states, "Significance expands. Meanings multiply". 49

It is interesting to note that Whiteson's gardening activities also attract wildlife - not an original gardening objective, but an effect he appreciates, and one that expands meaning in his space, as evidenced in his graphic description of a meditative morning in the garden:

If I stand very still here, in the buttery green-gold light of early morning, other creatures gather. A mockingbird settles in the jessamine to pluck the ripe white berries while making loud kissing sounds, like a mother planting a smackeroo on her baby's cheek. A scrub jay perches on the cherub fountain dish and spreads its tail in the cool water, pausing to release a raucous yawp. A pair of spotted doves cuddle in a corner, heads together, cooing intimately to one another. A flock of bushtits fills the air with twitterings and a bumblebee buries its face in a purple princess flower ...

A female possum stares at me from her hiding place in the trumpet vine, regarding me with ancient, myopic eyes, sniffing me out with her wet pink snout....

Then there's the multitude of insects. Swallowtail butterflies and painted ladies mingle with bees, wasps, hornets, midges, mites, spiders, ladybugs, crickets .... ${ }^{50}$

Harris, for her part, does not does set out to create wildlife habitat either, yet the fact that it attracts creatures beyond her and her immediate family is something she increasingly values as the space evolves. She even suggests the idea of gardening with the idea of habitat in mind for, as she specifies, squirrels and mice, wasps and bees, and "other living creatures beyond ourselves" 51 an approach she stresses as particularly important in a city environment. ${ }^{52}$ 
Although Stein's ecological efforts are the most direct, all three writers end up creating some sort of wildlife habitat and appreciating it - one of the pleasant surprises of participating as an active element in the garden's dynamic ecological community. The gardener-authors not only express themselves in meaningful ways, they also become actively involved with a green space and end up connecting with the nonhuman realm in an urban environment where such opportunities are limited — all in keeping with the garden's human-natural hybridity.

\section{Garden complexity, garden community}

From a human perspective, community is a "social network of interacting individuals, usually concentrated into a defined territory" ${ }^{53}$ From an ecological perspective, community is an "assemblage of organisms that live in a particular habitat and interact with one another", ${ }^{54}$ often interdependently. ${ }^{55}$ Considering the well-defined boundaries and territories of most personal gardens, along with their characteristic personal and social qualities, ecological relationships, and humannonhuman interactions, these spaces could definitely be considered hybrid human-natural communities. It follows that within the physical territory of the garden, within the set of relations that play out there, a particular sense of community would develop.

"Sense of community" is a concept in social psychology, specifically community psychology, which focuses on the experiences and meanings of community - on its relational aspect rather than its locational, territorial and geographical notions. Sense of community is characterized by feelings of belonging and identification, by emotional connection and senses of relatedness and mattering among group members. ${ }^{56}$ Although sense of community, also known as "psychological sense of community (PSOC)", ${ }^{7}$ is applied to the study of human communities, I am proposing that the concept also be used to understand the personal garden more fully as, in the words of Alexander Wilson, a "site of mediation between humankind and nature". 58

Personal gardens, after all, offer spaces where gardeners, active elements working with nature in the garden ecosystem ${ }^{59}$ - along with others using and visiting the garden such as family members, friends, and the public — have opportunities to observe the nonhuman world of the garden, to work with it, interact with it, and develop a growing appreciation for and deeper relationship with it.

\section{Garden relationships, garden senses of community}

$$
\begin{array}{r}
\text { What we need are more landscapes, more gardens, that truly reflect the variety and vitality of each community's character - and by } \\
\text { community, I mean not just the buman inhabitants, but the } \\
\text { communities of plants and animals which contribute so much to our sense of identity, } \\
\text { our sense of where exactly it is that we call home. }
\end{array}
$$

The relationships Marjorie Harris, Sara Stein and Leon Whiteson develop with their gardens are based on active, nurturing involvement with the spaces - involvement that leads to unique attachments, connections, and feelings of belonging and mattering to the space. It follows that each garden carries special personal meaning, a particular sense of community, for the gardener-author.

\section{Garden sense of community — friendship}

Sara Stein expresses her garden sense of community in very social terms. She views her gardening efforts as not so much a landscaping project "to be planted and done with", but more of a "friendship with the land", more of an ongoing and growing intimacy, ${ }^{61}$ that has her saying of a rocky corner that "'It wants ... some silvery business,' as one might say of a friend that she wants a 
good chat or a strong drink". ${ }^{2}$ The friendship with the land, Stein indicates, puts her at ease and enables her to make changes - move plants, re-route paths, shift the shape of beds, invite new species to participate - somewhat like, as she writes in an intriguing analogy of the garden as a social gathering, "moving a guest from one group to another or, as is sometimes necessary, showing an uncongenial one the door". ${ }^{63}$ Stein writes about expanding the guest list of the garden over time, and after each new invitation, waiting to see how things progress before introducing new acquaintances or old friends. ${ }^{64}$

One of Stein's favourite old friends is the blueberry, a plant she regards as responsive, flexible and sociable. Members of this "tribe", as she puts it, are "natural raconteurs, amusing birds with their witty ripening and keeping them in a flutter of attention for weeks during the summer." Blueberries have the common touch, she adds, describing them as "chummy with evergreens, comfy among flowers, at ease in tall grass, as much at home in a foundation planting as in a hedgerow." She adds that no one could ask for a less demanding friend ${ }^{65}$ — or a more valuable member of a garden community.

A sense of friendship with inhabitants of the land, and with the land itself, is something Stein also hopes to instil in young visitors to the garden. She describes her granddaughter, for example, as expecting "frogs to hop into her hands, bunnies to come to her for carrots, robins to lay their eggs in nests she makes of grass." While these are unrealistic notions ${ }^{66}$, she adds, they are also a good base of wonder for the care she hopes future generations will take of the nonhuman world ${ }^{67}$.

Stein could be accused of impractical idealism for the unrealistic notions she allows her granddaughter to cultivate, and of anthropomorphism for her sense of friendship with the land and the plants that grow there. Yet how else could she manage to encourage a sense of wonder in a garden visitor? How else could she describe a sense of community she genuinely feels to be a 'friendship'?

\section{Garden sense of community — learning}

Marjorie Harris openly admits to being anthropomorphic about her garden. "I quite often refer to plants as "those little guys over there" she writes, adding that she did not always feel that close to her plants. "When I started out", she reveals, "they were the Other. Something that would or wouldn't grow for me ... Now I see them as little creatures to be handled properly, that have personal likes and dislikes", ${ }^{6}$ each an individual member of her garden community. The garden as a whole means many different things to Harris - a site for artistic expression, as already discussed, as well as a place for personal ritual ${ }^{69}$ and an outlet for and source of energy. ${ }^{70}$ What comes up most frequently and consistently, however, are references to the garden as a learning site, the garden as a teacher.

When Harris starts to garden in the city, for example, she realizes with a shock that urban living has desensitised her to the natural environment. She recognises, at the same time, that she must learn more about her garden space, and that she must allow it to teach her. "At the garden's urging", she writes, she starts recording observations such as weather patterns and plant blooming periods ${ }^{71}$. She also writes about other, varied learning opportunities and experiences in the garden: an old lilac bush teaching her about nurturing: ${ }^{72}$ lessons from planting mistakes and plant deaths; ${ }^{73}$ plants revealing their interdependency, leading her to realise our profound dependence on plants. ${ }^{74}$

Harris also learns through the experiences others have in her garden. She writes, for example, about learning to let the garden delight her senses by following her grandson's sensory explorations of the garden space - poking his nose into plants, crushing flowers in his hands. ${ }^{75}$ She adds, "I look longingly at the next generation, wondering how I can plant the seeds of future passion there" an echo of Stein's wish to instil a sense of wonder and caring in future generations. As a whole, 
Harris writes, "My garden is my library, my teacher and guide" 77 - a powerful statement on the significant role the garden plays in her life, and the compelling sense of community she feels there.

\section{Garden sense of community - symbiosis}

The personal garden plays an equally significant, and intensely intimate, role in Leon Whiteson's life. He describes the garden as an integral part of himself, and he of it - a reflection of his close union with the space, and the symbiotic ${ }^{78}$ sense of community that develops there. The symbiosis is grounded in the satisfaction he feels at his physical involvement in the garden space — "the honest sweat generated by hacking at the earth" - which he finds to be a relief from the tension of writing, typing and "wrestling with verbal abstractions". ${ }^{79}$ Writing and gardening eventually grow into a balanced rhythm, a "pleasing back-and-forth" between mental tension and physical exertion. ${ }^{80}$

The garden is also, as Whiteson quickly realizes, "a living thing requiring constant care to sustain and order its redemptive powers" and it suffers if he deprives it of his physical participation for more than a day or two. He sees the evidence in wilting leaves, rampant morning glories, thirsty shrubs, clogged fountains - "forces of entropy at work" 81 — and he responds by lavishing constant care on the space, care which develops into a "nurturing intimacy" with the individual plants of the garden. He discovers "creative energy" flowing both ways, with the garden losing its distinction and definition without his daily attentions, and his soul losing inspiration without the garden's "boundless vigor" to stimulate him. "Soon thoughts of gardening and thoughts of writing were entwined," he writes, "like twin vines flourishing day and night in my head.... I created a mental garden to match the one in my backyard, imprinting the garden on my spirit just as my spirit was imprinted on the garden. ${ }^{83}$

He writes further that the garden has an increasingly powerful impact on him, seeping deep into his bones, smoothing out his short-term mood swings, soothing him in a "new intimacy with the cyclical life of the natural sphere" and giving him an overall sense of balance ${ }^{84}$ in return for his care and nurturing. So synergetic does the relationship become that Whiteson sees his own burial in the garden:

I see myself planted in the warm soil of my garden, wrapped in a shroud of giant banana leaves. Yet, lying in my grave, I feel more alive than ever.

The earth is active around me, dense with roots pushing through the ground, busy with earthworms chewing up rich grains of black clay, thick with nutrients to feed the foliage pushing toward the light above my buried body. Through the porous membrane of the banana skins I feel the earth's good energies ${ }^{85}$.

The vision is fleeting, but the earth's good energies remain, connecting his head with his hands, rooting both sensibilities in shared ground, and as he articulates, "cultivating a quietness I never knew could flourish in the agitated soil of my temperament." In these ways, he adds, the garden has made him, even as he has made it ${ }^{86}$ - a powerful statement of meaning and symbiotic sense of community.

\section{Tension in paradise}

The relationships of friendship, learning and symbiosis that Marjorie Harris, Sara Stein and Leon Whiteson develop with their gardens are intimate, compelling, and unique. The senses of community that grow there are strong and significant. Yet, as in every community and every relationship, differences and tension are bound to arise. Stein, for example, despite the ecological success of her 
garden, must make continuing efforts to restrain a persistent and overpowering non-native buckthorn species that threatens to invade her land. ${ }^{87}$ The "thrill beyond description" she experiences at her first sight of a doe with fawns in her rehabilitated garden is compromised, a decade later, by a population explosion among the "house rats with hooves", as she calls them, who eat the seedlings in her tree nursery and the baby trees growing naturally in her woodland. ${ }^{88}$

Harris, who stresses the need to garden with the idea of habitat in mind for various wild species including mice and squirrels, ${ }^{89}$ declares when squirrels dig up bulbs in her garden, that most of the time she finds herself hating them — at the same time acknowledging their ecological role in contributing to the survival of future botanical generations by distributing seeds and nuts. "They [squirrels] are sent to drive me insane" she writes. "I plant, they pull up" much frustration over the raccoons who tear water plants from her fountain and hurl them around every night. ${ }^{91}$ And she is equally unsympathetic toward Creeping Jenny, an effective, swift-spreading ground cover she originally planted to stabilize the soil in a certain part of her garden, but which she has since spent years pulling out. ${ }^{92}$

Whiteson, who delights in the mockingbirds, scrub jays, spotted doves, and other bird species who visit the garden in the early morning, ${ }^{93}$ is disturbed by one particular avian visitor — the only one of the gardener-authors to find a bird menacing. "One morning, stepping out of my office door," he explains, "I became aware of a giant presence hovering just above my head." It turns out to be a wood stork, perched on the trellis, spreading its four-foot-long wings to the sun, dwarfing all the other birds in the garden. "It was like a visitor from another dimension," he writes, "as its presence seemed to darken the sky and diminish the scale of the place." He is relieved when it departs $^{94}$. A non-human presence that does not, however, depart is a certain black neighbourhood tomcat who keeps returning to the garden no matter how often or irately Whiteson chases him off. ${ }^{95}$

These tensions are part of the ongoing dynamics of the personal garden community, part of its exuberance, its inscrutability, its unpredictability - all of which in turn are part of what Sarah Whatmore calls "the livingness of the world" and what Mitch Rose describes as "the overabundance of life in general." $"$ When a gardener engages with the garden space, she or he enters into a complex relationship with the living life of the garden, including its many non-human and human residents and visitors, as well as human constructions and artefacts. Associations among the many non-human garden residents/visitors, plus relations between them and the garden environment, influence the relationship between the gardener and the garden. The result of these entangled relationships, these living and overabundant "flows and connections," 98 to echo Gillian Rose, is that the garden community never stays the same. It changes constantly, from year to year, season to season, week to week - sometimes as frequently as day to day, minute to minute.

This continual change, with its associated uncertainty and unpredictability, is the result of what Sarah Whatmore terms the "creative presence of non-humans in the fabric of social life," non-humans conduct themselves as "active subjects in the geographies they help to fashion." 100 The geography of the personal garden — shaped by diverse biological organisms, including the gardener, interacting actively and creatively within complex relationships — is a landscape "co-fabricated between more-than-human bodies and a lively earth," "101 an achievement of soils, plants, animals and people, including the gardener's "animal sensibilities," 102 working in and through "fluid ecologies". ${ }^{103}$ It is clear, considering the outdoor, ecological nature of the garden, that it is not an exclusively human achievement. Less clear and less predictable, sometimes undesirable, is the non-human energy and activity in the garden.

What, then, of the gardener's personal vision for the garden's desired shape? What of his or her efforts to, in the words of Whiteson, "sustain and order"104 the space to help it maintain its distinctive character? As another gardener-author, Diane Ackerman, writes: 
A creeping obsession that afflicts many gardeners is the desire to triumph over the forces of chaos and disorder, battle the unruliness of growing things, cage beauty, impose a firm bridle on the natural world. This urge for order steals into a gardener's sensibility, and soon one is lamenting the frustrations of staking, mowing, uprooting, deadheading, pinching back, weeding, training, trimming, watering. Gardeners wage a secret war against nature's teeming jungle, which threatens to suffocate them. ${ }^{105}$

In the spirit of this secret war against the threat of nature, Stein encloses part of her garden with electric fencing to keep out the deer, and both she and Harris continue to remove unwanted plants from their gardens. Yet order cannot always be maintained. The black tomcat keeps returning to Whiteson's garden. And raccoons will not stop tearing water plants from Harris' fountain. What is the gardener to do in the face of continuing unruliness and disorder?

The answer lies in tempering the desire for order, in recognizing that control is an illusion. Ackerman, for example, acknowledges that her garden is a "landscape where anarchy rules" and that any order she achieves is temporary, "a flash of control in a wilderness of thieves". ${ }^{106}$ Patrick Lane agrees. Living things, particularly plants, he writes, "don't always obey even if the space, the light, and the earth and water are exactly right. What is propitious to the gardener is not always so for the plant". ${ }^{107} \mathrm{He}$ adds that plants never behave as he expects them to, "nor should they ... Who am I to insist that they grow in a certain spot and stay there?"108

In such cases of disorder, lack of obedience, and seeming anarchy, in the face of non-human forces beyond control, the gardener must be willing to renegotiate his or her relationship with the garden. And so Harris makes the decision to stop growing water plants, ${ }^{109}$ and Whiteson comes to a "wary détente" with the tomcat: "I ruled at ground level, he ruled at trellis level, eight feet up" both re-negotiations of the entangled rapport between human and non-human bodies active in the garden, both concessions that help the gardener manage the garden successfully, despite not achieving initial, ideal goals for the space. Ackerman, in fact, suggests that a useful goal of gardening is "Learning to live with compromise, uncertainty, and failure," 111 while Lorraine Johnson points out that garden failures are "full of wisdom and teaching ... a gentle tweak from the cosmos on the subject of control." 112 These lessons — in failure, negotiation, and compromise — add another layer of meaning to the personal garden, deepen the personal garden sense of community, and help unfurl the gardener's physical and conceptual horizons.

\section{Garden connections, expanded communities}

A true garden is never apart from its landscape. It arises from it like Eve from Adam's rib; it makes love
to the fields in the language of botany. ${ }^{113}$

The lessons of the personal garden, its meanings, its senses of community inevitably reach beyond the garden's boundaries to embrace wider urban communities and the greater natural environment. Marjorie Harris, Sara Stein and Leon Whiteson, to varying degrees, make both social and natural, inevitably hybrid, connections which expand their senses of community.

\section{Eclectic associations}

Whiteson's garden connects with the greater environment and community in typically eclectic fashion. Geologically, for example, Whiteson links his garden to the surrounding landscape through rocks, which he feels are appropriate emblems of the region's character - specifically its unstable geology which, he stresses, "looms largest in every Angeleno's consciousness of the surrounding natural forces." Stones, he adds, are also "symbols of endurance under time's stress". ${ }^{114}$ And so, as passionately as he scavenges artefacts, Whiteson collects rocks from the region - sandstone boulders from Mulholland Drive, rounded sea stones from Malibu, iron red rocks from the peak of 
Dante's View in Death Valley ${ }^{115}$ — and adds them to his garden, a space he describes as an "eclectic jumble of plants ... an artificial environment, like most of the region's greenery". ${ }^{116}$ The parallel he draws is based on his garden's botanical content - species from all continents, from all climate zones, tropical to alpine — which reflects Los Angeles in the way the city "defies its native landscape." 117

Los Angeles, he observes, "is altogether an act of imaginative, wilful invention, a habitable fantasia written large in a semidesert landscape transformed by the importation of water from sources in the sierras and deltas hundreds of miles to the north and from the Colorado River to the east". ${ }^{118}$ This importation of water is critical, he stresses, to human occupancy of the region and to creating moister conditions which allow for the proliferation of foreign plant species. The native vegetation - sagebrush, California poppy, wild lilac, manzanita, scrub oak - has in the meantime retreated to the windswept hills ${ }^{119}$ because the conditions under which it evolved have changed to the point where the plants no longer feel at home. "In the plant world as in the human," he writes, "Los Angeles is the territory of the self-invented dreamer, a country of the mind where anyone may create any naturalistic or surreal scenario imaginable, a place both mad and bland, wacky and smug. ${ }^{120}$ In that context, Whiteson's own garden, with its carefully selected rocks, wide diversity of plants, and eccentric collection of artefacts, could be considered a scenario both surreal and naturalistic - a blend in the spirit of the garden's essential hybridity.

Less surreal are the social connections Whiteson makes through his garden, located in a gentrified Hollywood neighbourhood. There, yards and gardens maintained by hired labourers result in a uniform scene of "boring rose beds" and "bland lawns", a "landscape of gardens well kept but unstroked by hands-on affection, like pampered kids whose parents were too busy to cuddle them". ${ }^{121}$ Whiteson's garden, in contrast, is unique because of its diversity and the personal care he bestows on it. The front garden in particular — with its "wild assortment" of plants, including large and small trees, as well as unusual combinations of grasses and flowers - sticks out in the street, attracting the attention of people walking by, including joggers, dog walkers, homeless men and women, and other passers-by. These neighbourhood residents are people Whiteson looks forward to seeing and greeting. ${ }^{122}$

Yet the contact is not always positive. Some individuals, he points out, are suspicious about a homeowner doing his own gardening work, particularly the hard labour of digging and planting, and they stop to query him on his intentions. ${ }^{123}$ His presence in the front garden also, he points out, connects him with "a current of ugliness underlying the more amiable aspects of the neighborhood", ${ }^{124}$ specifically a controversy regarding the conversion of a local house into a hospice for AIDS patients. Neighbourhood residents either support or oppose the project, passionately sharing their opinions when they stop to chat with Whiteson as he works in his front garden. ${ }^{125}$

Whiteson also relates wider social tensions to his personal garden space. In the context of mounting friction preceding the Los Angeles riots of 1992, Whiteson realizes that in the vast sprawl of Los Angeles, many residents are concerned about defining their communities and protecting a sense of identity in the anonymity of the metropolis. "Since modern cities have burst their bounds," he writes,

and have become shapeless regional metropolises covering hundreds of square miles, no single citizen can hope to comprehend their enormity. Complex and confusing, these urban regions offer little sense of coherence when contemplated as a whole. The only way to cope with such vast social and geographic entities is to be rooted in your own defined, defended ground. ${ }^{26}$

Whiteson goes on to acknowledge his own rootedness in the "good green place"127 of his garden, defined and protected by high, overgrown walls which mark the boundary between assured safety 
and possible danger from the world outside. ${ }^{128}$ When riots do break out in the city, Whiteson feels that his sturdy green walls are all that stand between him and "the orgy of rampant violence ruling the streets." He adds the confession that had he possessed a firearm, he would have shot anyone who entered his garden, and that he actually kept a large, club-like avocado branch by the back gate for defence. ${ }^{129}$

Whiteson also writes that in the process of creating his garden he begins to grasp a vital paradox: that "Only the safety and identity of an intensely personal private place within a clear community can encourage each citizen to reach out for a genuine connection with the city at large" interesting statement on personal place and community. The clarity of Whiteson's community is something he does not address directly, yet it is something which appears to become defined as he interacts with people passing by his garden, and as he engages in local issues. As much as the garden is, for Whiteson, a place of intimate retreat and symbiosis with nature, it also becomes a conduit for connection with the social community beyond the garden walls.

\section{Uptown connections}

Harris does not delve as deeply into her garden's social connections to the greater urban community. Yet she does make reference to the greater community of gardeners when she writes about small groups of people visiting her garden during a fundraising event, ${ }^{131}$ about new friends she makes through gardening networks, ${ }^{132}$ and about the "sorority of gardeners" she encounters through travel, speaking engagements, and involvement in gardening groups. ${ }^{133}$

Harris makes additional human-natural associations when she traces the geological and landscape history affecting her garden. The site of her garden, she points out, was once at the bottom of Lake Iroquois, the endless motion of which smoothed out the glacial till of its bed, filling it with the dense clay and alluvial silt which now forms the subsoil of her garden. She adds that she can see evidence of the lake's retreat 10,000 years earlier in the memory of Taddle Creek, which had carved out a deep ravine and flowed into Seaton Pond, a small water body originally located at the bottom of her lot. When people settled the area in the $18^{\text {th }}$ century, she explains, they used Taddle Creek as a sewage dump. Later, when the area was subdivided into farms, the site of Harris's lot became part of an orchard. With time, as the town spread out into the country and the farms were subdivided again and again into lots, Taddle Creek was forced into cement pipes to contain sewage, with the result that both the creek and the pond disappeared from view and memory. ${ }^{134}$

Yet the land, it appears, does not forget. Each spring after a neighbouring lot - a large tangle of trees, shrubs and woodland plants, and a complex ecosystem with the capacity to absorb water - is sold and transformed into a parking lot, the water table rises to flood Harris' garden. ${ }^{135}$ Although the flood has obvious disadvantages, Harris recognizes that it brings nutrients to the surface from the clay-rich subsoil below ${ }^{136}$ and that it attracts migrating birds. Up to eighty species of birds have been counted in her spring pond, and it gives her great pleasure to watch flocks of birds splashing in the water. "The birds must retain Seaton Pond in their genetic memories", ${ }^{137}$ she notes.

Phenomena such as migrating birds passing through her garden prompt Harris to encourage readers to make connections beyond the boundaries of the garden, to think in a larger landscape context. She writes about the importance of studying what the landscape offers, understanding how we are connected with the natural environment, figuring out how to work with it, and being sensitive to needs other than our own. She also briefly discusses garden plots being part of a complex system essential to wildlife in city environments and the importance of providing habitat — food, shelter, and water - for wild animals. "When I contemplate how much land we gardeners own, abutting each other as we do," she muses, "I wonder why we don't organize. We could become a powerful lobby to protect the environment.",139 


\section{Intricate links}

The idea of studying what the landscape offers, of gardens abutting each other and connecting with natural areas, is what Sara Stein's gardening efforts are all about. Her garden, as already discussed, connects with the greater landscape in its overall design, inspired by the ecological Master Plan operating in the greater landscape. The notion of interconnection also fuels Stein's vision of the suburban landscape of the future: "suburbia re-growing into a continuity of woods, thickets, and meadows linking remnant refuges and reservations" "140 and creating what she calls "intelligent suburban ecosystems" ${ }^{\text {"141 }}$ that link gardens with each other and to the greater physical landscape in a great, interrelated, continuous whole benefiting the wildlife species who share the land.

Like Harris, Stein situates her garden space within the larger landscape and land use context of her region. The sloped land of her lot, she explains, lies below Great Hill, the highest point on a ridge that rises and falls along what was once the route of First Nations travelling between summer camps along the Connecticut shore, and inland winter bases. She adds that, according to her atlas' world vegetation map, this part of New England fits into the 'Broadleaf Forest' green patch covering approximately one third of the 48 contiguous states, and that the atlas' population distribution and density map shows the area to be highly populated. "A stranger would surmise," she observes with a wry twist, "that most Americans live in the woods" "142 when, in fact, Europeans had systematically clear-cut the forest with the following results:

In less than two centuries, each individual's picking added up to a collective assault so powerful as to literally make the streams run dry. Leaching, erosion, compaction, and dessication forced the abandonment of fields and pastures in New England and throughout the East beginning in the nineteenth century when, in the great westward migration, farmers plowed their way beyond the forest belt onto the rich American plains. ${ }^{143}$

Some of this degraded farmland, so hopeless it had to be abandoned, is the site of Stein's garden, located in an area where deserted agricultural land is being converted into suburbs. The farms there were, in fact, dealt a final coup de grace when despairing farmers scraped their fields of topsoil to supply the 1939 World's Fair. Any topsoil remaining when Stein arrived was situated in isolated pockets. The rest of the soil on Stein's portion of the slope was, as she describes it, "pale, hard, dry, and sterile" 144 — not conducive to successful gardening.

These abandoned farming areas, she points out, slowly become engulfed by suburbia and the accompanying spread of North America's clean, spare landscaping and gardening tradition, which has resulted in a landscape that devastates rural ecology, reduces natural habitats to dangerously low levels, wipes out entire communities of plants and insects and causes both local extinctions and the almost total extinctions of fragile species. ${ }^{145}$ But the habitat destruction can be reversed, she stresses, when people garden with a view to reconnecting plant and animal species and rebuilding self-sufficient suburban ecosystems - in effect, a new North American gardening culture. This new culture, Stein points out, requires a new kind of garden, new gardening techniques and, she stresses, a

new kind of gardener. She adds, in echo of Harris, that gardeners own a big chunk of the country ${ }^{146}$ and that if all were to plant a portion of the yard in a way that harmonizes with the ecosystem where they lived, the suburban landscape could eventually perform its own pest control, conserve its own water, maintain its own soil, and support its own animal associates ${ }^{147}$, essentially functioning according to the Master Plan.

Stein realizes, of course, that not everyone can accommodate the variety of habitats she creates on her large suburban lot. And she points out that not everyone can or should provide all sorts of habitat or all types of food. Together, however, like-minded gardeners could create a composite ecosystem, with neighbouring gardens, connected at the borders and along the edges, playing 
important roles in the food web and otherwise making a big difference. ${ }^{148}$ She describes this new landscape as "hedgerows instead of hedge (no trimming required); beds of prairie flowers (put away your hose, your pesticide sprayers); inkberries under oak trees (feed the birds for free): abundance". ${ }^{149}$ Stein even provides a possible design for a small urban plot — a design that accommodates a hedgerow, a meadow, a wooded corner, and space for a house and a lawn or terrace. The same design, placed back to back and side to side, she explains, creates a pattern of thickets, woodlots, meadows and hedgerows - a suburban ecosystem that could return as much as half the acreage to wildlife. She adds, in marketing style, a potential logo, "Grow America", and invites readers to join the club. ${ }^{150}$

The club could, in fact, include Harris and Whiteson, who both, by planting a diversity of vegetation, create habitat and attract different wildlife species, even though they do not originally intend to do so. In terms of human community, Whiteson writes most directly about making contact with people beyond the garden gate. Yet Harris also makes links through family and her gardening networks, and Stein connects to family and to people she meets as a popular spokesperson for the ecological gardening movement. ${ }^{151}$ All three gardener-authors also reach out to wider communities through their books.

Stein further expresses hope that our culture would as a whole, "depart from the old tradition of evaluating land according to what can be extracted from it as commodity or abstracted from it as social asset, and turn instead toward a new tradition of valuing land by the life it harbors". ${ }^{152}$ All three authors, at different points during the evolution of their garden relationships, and in different ways significant to each individual, begin to manifest this new tradition, to value the "livingness" 153 in not only the garden space, but also in the broader community beyond the garden's boundary. All three gardener-authors also come to recognize where they and their gardens fit into the greater environment, and the roles they play there.

\section{Complexity and opportunity, meaning and community}

When we garden, we may be escaping into a world we've created with care and labour and seeds and water and vision (perhaps even escaping into our own provisional version of paradise), but we are also participating in, and connecting with, something beyond ourselves; we are nurturing life. ${ }^{154}$

The personal garden — in all its "overabundance", 155 "creative presence", 156 "flows and connections," 157 exuberance and unpredictability — is clearly a hybrid space. As an outdoor setting for social contact and interaction, as a cultural space designed and shaped through human imagination and effort, as a personal space that carries particular and intimate meaning for the gardener, the garden is very human. As a space populated and visited by biological entities, including the gardener, who engage in intricate and necessary ecological relationships, dependent on and subject to greater environmental processes and systems, the garden is definitely natural. Abundantly intriguing and complex, the garden space allows for fascinating and surprising things to happen.

One of the most interesting things about the personal garden is the multiple opportunities it offers to individuals wishing to become physically involved with a green space. The garden is a place where gardeners can express themselves personally with the land - artistically, architecturally and ecologically, as expressed through the books of gardener-writers Marjorie Harris, Sara Stein, and Leon Whiteson. The garden is also a space where gardeners can participate actively as members of an ecological unit and in the process develop personal relationships and meaningful senses of community with an outdoor environment - senses, for example, of friendship, learning, symbiosis, and more. As these relationships develop, the garden invites and encourages gardeners to make connections beyond the garden's boundaries with the immediate neighbourhood, greater ecosystems, 
the gardening community, the regional landscape, and the city as a whole. In an urban environment where access to nature and green space is limited, the opportunities offered by the garden are significant. As Marjorie Harris writes, "For many of us, especially we who live in cities, a garden is the only contact with nature and our best source for understanding our relationship with the land."158

Harris, Stein and Whiteson, as homeowners living in single-family houses with adjacent space available for gardening, admittedly write from a privileged position. Not all city residents have access to home yards where they can create a garden. Yet other spaces are often available in cities: spaces that stretch the gardener's imagination and creativity, spaces that provide opportunities for equally rich and meaningful relationships and connections. Balconies and rooftops, for example, can accommodate flower pots and planters. Community gardens offer plots where individuals can work the soil, grow vegetables and herbs for food, cultivate flowers for aesthetics, and develop friendships with like-minded individuals. Vacant lots, neglected sidewalk planters, and other unplanted and unloved city grounds, present space where brave and enterprising urban citizens can take guerrilla gardening initiative. Schoolyards provide opportunities for volunteers to till the soil, engage the energies and imaginations of future generations, and enhance both student outdoor areas and urban biodiversity.

Some of these spaces may not be as private or as intimate as backyard gardens. They may be open to critical scrutiny, vulnerable to vandalism, and threatened by competing uses or municipal bylaws. But they nevertheless provide opportunities for city dwellers to become involved with the "livingness"159 of a green space, however small; to express personal tastes and values; to develop relationships with human and nonhuman residents, visitors and passers-by; to grow dynamic and meaningful senses of community and home; and to connect with the greater natural environment and urban community.

All these opportunities taken by urban residents to nurture and reach out from green spaces small and large, private and public, in the backyard or down the street, contribute significantly to the health of the natural environment, the wellbeing of the individuals involved with the space, and ultimately the continuing vitality of the community at large. There is no shortage of examples and studies demonstrating that gardening is good for people and communities. ${ }^{160}$ This is why gardening is so significant, especially to cities. This is why we need more spaces in urban environments where people can tend the earth. This is why we need municipalities and urban authorities committed to providing spaces where people can garden, to ensuring the survival of those spaces by building their protection into urban plans and regulations, and to encouraging urban citizens to take advantage of the opportunities to nurture the land. The health of communities and the planet, Lorraine Johnson points out, depends on people connecting with their home places, learning about them and understanding them, seeing and feeling what people are doing to them and what is happening to the earth. "We need stewards and nurturers and people who care," she writes. "We need gardeners". ${ }^{161}$

1 Lorraine Johnson, The Gardener's Manifesto: Changing the World and Creating Beauty One Garden at a Time (Toronto:

Penguin Canada, 2002), xvi.

2 Patrick Lane, There Is a Season: A Memoir in a Garden (Toronto: McClelland \& Stewart, 2004), 14.

3 Nathalie Ban and Oliver Coomes, "Home Gardens in Amazonian Peru: Diversity and Exchange of Planting Material," The Geographical Review 94, no. 3 (2004): 348-67.

4 Russell Hitchings, "People, Plants and Performance: On Actor Network Theory and the Material Pleasures of the Private Garden," Social and Cultural Geography 4, no. 1 (2003): 99-113.

5 Stephen Williams, "No Place Like Home - the Role of Domestic Gardens as Recreational Spaces," in Outdoor Recreation and the Urban Environment (New York: Routledge, 1995). 
6 Lesley Head, Pat Muir, and Eva Hampel . "Australian Backyard Gardens and the Journey of Migration," The Geographical Review 94, no. 3. (2004): 326-47.

7 Maria Elisa Christie, "Kitchenspace, Fiestas, and Cultural Reproduction in Mexican House-Lot Gardens," The Geographical Review 94, no. 3 (2004): 368-90.

8 I use this word with apprehension, fraught as it is with controversy and debate. The purpose of this article not being to enter into the discussion about "nature", I will continue to use the word and its associated adjective, albeit as little as possible, in figurative quotation marks. And I will leave those words as I find them when I quote and paraphrase references.

9 I use this word in full awareness that "nature" is an idea fraught with complexity, ambiguity and conflict, a discussion of which does not enter into the scope of this article.

10 This book is curious in that it contains no page numbers. Yet each page in the book contains a different, brief, titled meditation on Harris' garden. When I reference this book, I will, therefore, be unable to provide the page number, which is absent, but I will specify the title of the particular meditation referred to.

11 Unfortunately Sara Stein lost her life to lung cancer in 2005. She was 69.

12 Gillian Rose, "Hybridity" in The Dictionary of Human Geography, ed.. R.J. Johnston, et al (Malden, MA: Blackwell Publishers, 2000), 364.

13 Katharyne Mitchell, "Hybridity," in Cultural Geography: A Critical Dictionary of Key Concepts, ed. David Sibley, et al (London and New York: I.B. Tauris, 2005), 188.

14 Sander-Regier, 2006.

15 Ibid.

16 Gillian Rose, "Hybridity" in The Dictionary of Human Geography, ed. R.J. Johnston, et al (Malden, MA: Blackwell Publishers, 2000), 364.

17 Peirce F Lewis, "Axioms for Reading the Landscape: Some Guides to the American Scene," in The Interpretation of Ordinary Landscapes, edited by D.W. Meinig (New York: Oxford University Press, 1979), 12.

18 Marjorie Harris, Seasons of My Garden (Toronto: HarperCollins,1999), xxii.

19 Ibid, 75.

20 Marjorie Harris, In the Garden: Thoughts on Changing Seasons (Toronto: HarperCollins, 1995), "Color".

21 Marjorie Harris, Seasons of My Garden (Toronto: HarperCollins, 1999), x, 122.

22 Ibid, ix-xi

Marjorie Harris, In the Garden: Thoughts on Changing Seasons (Toronto: HarperCollins, 1995) "A garden epiphany".

Marjorie Harris, Seasons of My Garden (Toronto: HarperCollins, 1999), x-xii.

Marjorie Harris, Seasons of My Garden (Toronto: HarperCollins,1999), 120.

Marjorie Harris, In the Garden: Thoughts on Changing Seasons (Toronto: HarperCollins, 1995), "Evergreens".

Marjorie Harris, Seasons of My Garden (Toronto: HarperCollins, 1999), 69.

Ibid, "Pleasure of the eye".

Leon Whiteson, A Garden Story (Boston: Faber and Faber, 1995), 6-7.

Ibid, 33-4.

Ibid, 11-13.

Ibid, 12.

Ibid, 74.

Ibid, 89.

Ibid, 88-9.

Ibid, 77.

Sara Stein, Noab's Garden: Restoring the Ecology of Our Backyards (New York: Houghton Mifflin, 1993$), 9$.

Ibid, 18.

Ibid, 73.

Ibid, 74 .

Ibid, 74 .

Ibid, 17.

Ibid, 179-188.

Ibid, 161-171.

Ibid, 17.

Ibid, 57.

Ibid, 18.

Ibid, 246.

Ibid, 245. 
Whiteson, A Garden Story (Boston: Faber and Faber, 1995), 164.

Marjorie Harris, In the Garden: Thoughts on Changing Seasons (Toronto: HarperCollins, 1995), "The controlling hand". Ibid, "The larger context".

Ron Johnston "Community." In The Dictionary of Human Geography, ed. R.J. Johnston, Derek Gregory, Geraldine Pratt and Michael Watts.(Malden, MA: Blackwell Publishers, 2000), 101.

54 Mark V. Lomolino, Brett R. Riddle, and James H. Brown. Biogeography. 3rd ed. (Sunderland, MS: Sinauer Associates, 2006), 756.

55 William Marsh and John Jr. Grossa, Environmental Geography: Science, Land Use, and Earth Systems (New York, Toronto, Singapore: John Wiley \& Sons, 1996), 399.

56 David W. McMillan and David M. Chavis,. "Sense of Community: A Definition and Theory,"Journal of Community Psychology 14 (1986): 6-23.

57 Patricia L. Obst and Katherine M. White, "An Exploration of the Interplay between Psychological Sense of Community, Social Identification and Salience," Journal of Community \& Applied Social Psychology 15 (2005): 127-35.

58 Alexander Wilson, The Culture of Nature: North American Landscape from Disney to the Exxon Valdez. (Toronto: Between the Lines, 1991), 97.

59 Bruce Allsop, Ecological Morality (London, UK: Frederick Muller, 1972), 40-48.

60 Lorraine Johnson, Grow Wild! Native Plant Gardening in Canada and Northern United States (Toronto: Random House of Canada, 1998), 7.

61 Sara Stein, Noah's Garden: Restoring the Ecology of Our Backyards (New York: Houghton Mifflin, 1993), 219.

62 Ibid, 219.

63 Ibid, 219.

64 Ibid, 216.

65 Ibid, 216.

66 Ibid, 238-9.

67 Ibid, 190.

68 Marjorie Harris, In the Garden: Thoughts on Changing Seasons (Toronto: HarperCollins, 1995), "Anthropomorphism".

69 Ibid, "Evening ritual".

70 Ibid, "Energy".

71 Marjorie Harris, Seasons of My Garden (Toronto: HarperCollins,1999), x.

72 Marjorie Harris, In the Garden: Thoughts on Changing Seasons (Toronto: HarperCollins, 1995), "The old lilac".

73 Ibid, 44.

74 Marjorie Harris, In the Garden: Thoughts on Changing Seasons (Toronto: HarperCollins, 1995), "Points of view".

75 Ibid, "Relearning the senses".

76 Ibid, "Children in the garden".

77 Ibid, "Finale".

78 Richard T Wright, Environmental Science: Toward a Sustainable Future, 9th ed (Upper Saddle River, NJ: Pearson-Prentice Hall, 2005), 41.

79 Leon Whiteson, A Garden Story (Boston: Faber and Faber, 1995), 35.

80 Ibid, 35 .

81 Ibid, 155.

82 Ibid, 39.

83 Ibid, 132-33.

84 Ibid, 168.

85 Ibid, 162

86 Ibid, 168.

87 Sara Stein, Noah's Garden: Restoring the Ecology of Our Backyards (New York: Houghton Mifflin, 1993), 199.

88 Ibid, 77-79.

89 Marjorie Harris, In the Garden: Thoughts on Changing Seasons (Toronto: HarperCollins, 1995), "The controlling hand".

90 Ibid, "Squirrels".

91 Ibid, 6.

92 Marjorie Harris, Seasons of My Garden (Toronto: HarperCollins, 1999), 44.

93 Leon Whiteson, A Garden Story (Boston: Faber and Faber, 1995), 164

94 Ibid, 136.

95 Ibid, 58

96 Sarah Whatmore, "Materialist Returns: Practising Cultural Geography in and for a More-Than-Human World" Cultural Geographies 13 (2006): 602. 
97 Mitch Rose, "Landscape and Labyrinths," Geoforum 33 (2002): 460.

98 Gillian Rose, "Hybridity" in The Dictionary of Human Geography, ed. R.J. Johnston, et al (Malden, MA: Blackwell Publishers, 2000), 364.

99 Sarah Whatmore, Hybrid Geographies: Natures, Cultures, Spaces, (London, Thousand Oaks, New Delhi: Sage Publications, 2002), 35-36.

100 Ibid, 14.

101 Sarah Whatmore, "Materialist Returns: Practising Cultural Geography in and for a More-Than-Human World," Cultural Geographies 13 (2006): 603.

102 Sarah Whatmore, Hybrid Geographies: Rethinking the 'Human' in Human Geography, in Human Geography Today, ed. Doreen Massey et al (Oxford, Cambridge, Malden: Polity Press, 1999), 35.

103 Sarah Whatmore, Hybrid Geographies: Natures, Cultures, Spaces (London, Thousand Oaks, New Delhi: Sage Publications, 2002), 14

104 Ibid, 155.

105 Ibid, 245.

106 Ibid, 245.

107 Patrick Lane, There Is a Season: A Memoir in a Garden (Toronto: McClelland \& Stewart, 2004), 204.

108 Ibid 100.

109 Marjorie Harris, Seasons of My Garden (Toronto: HarperCollins,1999), 6.

110 Leon Whiteson, A Garden Story, (Boston: Faber and Faber, 1995), 58.

111 Diane Ackerman, Cultivating Delight: A Natural History of My Garden (New York: HarperCollins, 2001), 69.

112 Lorraine Johnson, The Gardener's Manifesto: Changing the World and Creating Beauty One Garden at a Time (Toronto: Penguin Canada, 2002), xxi.

113 Douglas Chambers, Stony Ground: The Making of a Canadian Garden (Toronto: Alfred A. Knopf, 1996), xiii.

114 Leon Whiteson, A Garden Story (Boston: Faber and Faber, 1995), 87.

115 Ibid, 88.

116 Ibid, 86-87.

117 Ibid, 87.

118 Ibid, 17.

119 Ibid, 18.

120 Ibid, 17-19.

121 Ibid, 56-7.

122 Ibid, 52-6.

123 Ibid, 56-7.

124 Ibid, 60.

125 Ibid, 61-3.

126 Ibid, 63-4.

127 Ibid, 155.

128 Ibid, 64-5.

129 Ibid, 152.

130 Ibid, 68.

131 Marjorie Harris, In the Garden: Thoughts on Changing Seasons (Toronto: HarperCollins, 1995), "The garden party".

132 Ibid, "A garden epiphany".

133 Ibid, "The sorority of gardeners".

134 Marjorie Harris, Seasons of My Garden (Toronto: HarperCollins,1999), x.

135 Marjorie Harris, In the Garden: Thoughts on Changing Seasons (Toronto: HarperCollins, 1995), "Revenge of nature".

136 Marjorie Harris, Seasons of My Garden (Toronto: HarperCollins,1999), 5.

137 Ibid, $x$ and 5.

138 Marjorie Harris, In the Garden: Thoughts on Changing Seasons (Toronto: HarperCollins, 1995), "The larger context".

139 Ibid, "Working with Nature".

140 Sara Stein, Noah's Garden: Restoring the Ecology of Our Backyards (New York: Houghton Mifflin, 1993$), 251$.

141 Ibid, 16.

142 Ibid, 20.

143 Ibid, 21.

144 Ibid, 21.

145 Ibid, 9-10.

146 Ibid, 16. 
147 Ibid, 44-45.

148 Ibid, 97.

149 Ibid, 18.

150 Ibid, 19.

151 Book cover content: Sara Stein, Planting Noab's Garden: Further Adventures in Backyard Ecology (Boston: Houghton Mifflin, 1997) and Noab's Children: Restoring the Ecology of Childhood (New York: North Point Press, 2001).

152 Ibid, 244.

153 Sarah Whatmore, "Materialist Returns: Practising Cultural Geography in and for a More-Than-Human World," Cultural Geographies 13 (2006): 602.

154 Lorraine Johnson, The Gardener's Manifesto: Changing the World and Creating Beauty One Garden at a Time, (Toronto: Penguin Canada, 2002), xvi.

155 Mitch Rose, "Landscape and Labyrinths," Geoforum 33 (2002): 460.

156 Sarah Whatmore, Hybrid Geographies: Natures, Cultures, Spaces (London, Thousand Oaks, New Delhi: Sage Publications, 2002), 35-36.

157 Gillian Rose, "Hybridity" in The Dictionary of Human Geography, ed. R.J. Johnston, et al (Malden, MA: Blackwell Publishers, 2000), 364.

158 Marjorie Harris, introduction to In the Garden: Thoughts on Changing Seasons (Toronto: HarperCollins, 1995),

159 Sarah Whatmore, "Materialist Returns: Practising Cultural Geography in and for a More-Than-Human World," Cultural Geographies 13 (2006): 602.

160 Lorraine Johnson, The Gardener's Manifesto: Changing the World and Creating Beauty One Garden at a Time (Toronto: Penguin Canada, 2002), 138-154.

161 Ibid, xxv.

\section{Bibliography}

Allsop, Bruce. Ecological Morality. London, UK: Frederick Muller, 1972.

Ban, Nathalie, and Oliver Coomes. "Home Gardens in Amazonian Peru: Diversity and Exchange of Planting Material." The Geographical Review 94, no. 3 (2004): 348-67.

Chambers, Douglas. Stony Ground: The Making of a Canadian Garden. Toronto: Alfred A. Knopf, 1996.

Christie, Maria Elisa. "Kitchenspace, Fiestas, and Cultural Reproduction in Mexican House-Lot Gardens." The Geographical Review 94, no. 3 (2004): 368-90.

Harris, Marjorie. In the Garden: Thoughts on Changing Seasons. Toronto: HarperCollins, 1995.

- Seasons of My Garden. Toronto: HarperCollins, 1999.

Head, Lesley, Pat Muir, and Eva Hampel. "Australian Backyard Gardens and the Journey of Migration." The Geographical Review 94, no. 3. (2004): 326-47.

Hitchings, Russell. "People, Plants and Performance: On Actor Network Theory and the Material Pleasures of the Private Garden." Social and Cultural Geography 4, no. 1 (2003): 99-113.

Johnson, Lorraine. Grow Wild! Native Plant Gardening in Canada and Northern United States. Toronto: Random House of Canada, 1998.

- The Gardener's Manifesto: Changing the World and Creating Beauty One Garden at a Time. Toronto: Penguin Canada, 2002.

Johnston, Ron, Derek Gregory, Geraldine Pratt, and Michael Watts. "Community." In The Dictionary of Human Geography, edited by R.J. Johnston, Derek Gregory, Geraldine Pratt and Michael Watts. Malden, MA: Blackwell Publishers, 2000.

Lane, Patrick. There Is a Season: A Memoir in a Garden. Toronto: McClelland \& Stewart, 2004.

Lewis, Peirce F. "Axioms for Reading the Landscape: Some Guides to the American Scene." In The 
Interpretation of Ordinary Landscapes, edited by D.W. Meinig. New York: Oxford University Press, 1979.

Lomolino, Mark V., Brett R. Riddle, and James H. Brown. Biogeography. 3rd ed. Sunderland, MS: Sinauer Associates, 2006.

Marsh, William, and John Jr. Grossa. Environmental Geography: Science, Land Use, and Earth Systems. New York, Toronto, Singapore: John Wiley \& Sons, 1996.

McMillan, David W., and David M. Chavis. "Sense of Community: A Definition and Theory." Journal of Community Psychology 14 (1986): 6-23.

Mitchell, Katharyne. "Hybridity." In Cultural Geography: A Critical Dictionary of Key Concepts, ed.David Sibley, Peter Jackson, David Atkinson and Neil Washbourne. London and New York: I.B. Tauris, 2005.

Rose, Gillian. "Hybridity" In The Dictionary of Human Geography, ed. R.J. Johnston, Derek Gregory, Geraldine Pratt and Michael Watts. Malden, MA: Blackwell Publishers, 2000.

Rose, Mitch. "Landscape and Labyrinths." Geoforum 33 (2002): 455-67.

Sander-Regier, Renate. 2006. A Place between Heaven and the Heart: A geographical interpretation of selected contemporary personal gardening literature. Ottawa: University of Ottawa, Geography thesis.

Stein, Sara. Noah's Garden: Restoring the Ecology of Our Backyards. New York: Houghton Mifflin, 1993.

-. Planting Noah's Garden: Further Adventures in Backyard Ecology. Boston: Houghton Mifflin, 1997.

- Noah's Children: Restoring the Ecology of Childhood. New York: North Point Press, 2001.

Whatmore, Sarah. "Hybrid Geographies: Rethinking the 'Human' in Human Geography." In Human Geography Today, ed. Doreen Massey, et al. Oxford, Cambridge, Malden: Polity Press, 1999.

- Hybrid Geographies: Natures, Cultures, Spaces. London, Thousand Oaks, New Delhi: Sage Publications, 2002.

—. "Materialist Returns: Practising Cultural Geography in and for a More-Than-Human World." Cultural Geographies 13 (2006): 600-09.

Whiteson, Leon. A Garden Story. Boston: Faber and Faber, 1995.

Williams, Stephen. "No Place Like Home - the Role of Domestic Gardens as Recreational Spaces." In Outdoor Recreation and the Urban Environment. New York: Routledge, 1995.

Wilson, Alexander. The Culture of Nature: North American Landscape from Disney to the Exxon Valder: Toronto: Between the Lines, 1991.

Wright, Richard T. Environmental Science: Toward a Sustainable Future. 9th ed. Upper Saddle River, NJ: Pearson, Prentice Hall, 2005. 